\title{
Instrument Development “Intention to Stay Instrument” (ISI)
}

\author{
Dileep Kumar M. ${ }^{1} \&$ Normala S. Govindarajo ${ }^{1}$ \\ ${ }^{1}$ Othman Yeop Abdullah Graduate School of Business, University of Utara Malaysia, Sintok, Malaysia \\ Correspondence: Dileep Kumar M., Othman Yeop Abdullah Graduate School of Business, Universiti Utara \\ Malaysia, Sintok, Kedha, Malaysia. Tel: 60-17-415-2541. E-mail: dileep@uum.edu.my
}

Received: March 2, 2014 Accepted: March 31, 2014 Online Published: May 26, 2014

doi:10.5539/ass.v10n12p149 URL: http://dx.doi.org/10.5539/ass.v10n12p149

\begin{abstract}
Quite a few instruments exist in literature to measure the concepts like absenteeism, attrition, organizational member's intention to leave and retention. While, there is always confusion between the variable's and its appropriateness when contextualize the topic to various industries, sectors and regional applications. These variances evidently may observe when an instrument developed in the west and apply it in east to get its validity and reliability. In this context, an instrument developed to measure the causative factors of 'member's intention to stay', especially focused on individual and organizational factors in the manufacturing sector. The instrument development process was initially followed the qualitative research method. Techniques like content analysis, personal interviews with the organizational members, focus group discussion and Delphi technique were adopted. After identification of the variables through Delphi, these variables were exposed to validity and reliability test. Further, content, construct and face validity was made on the sub factors and items generated in the instrument. The instrument was finalized with 76 items under 21 sub factors of 'member's intention to stay'.
\end{abstract}

Keywords: intention to leave, instrument, Delphi technique, factor analysis

\section{Introduction}

Many researchers have tried to answer this question, why employees leave an organization. (Bluedorn, 1982; Kalliath \& Beck, 2001; Kramer et al., 1995; Peters et al., 1981; Saks, 1996). Some authors argued individual factors and some other related organizational factors. As such, there is little consistency in their observations and findings. This indicates that an exploration of the theme 'member's intention to stay' in an organization to be made, by contextualizing the situation to manufacturing industries. In this scenario, several authors tried to explore several means to explain the same phenomena 'members intention to leave or stay back in organization' contextualizing the topic to varied sectors, industries and regions. Thus, this study was concentrated in the Asian region, especially from India, and the companies in the manufacturing sector. This instrument development research follows qualitative and quantitative research to fix the variables under study. In order to get the reliability of factors leading to 'member's intention to stay' in organizations, five companies belonged to the manufacturing sector, situated in varied locations, were studied into. The study, thus have the objective of development of an instrument in identifying and fixing variables related to 'member's intention to stay' in manufacturing companies.

\section{Review of Literature}

Employee turnover is an extensively researched issue of organizational psychologists. There have been several hundred studies carried out on employee turnover since 1900 (Cotton \& Tuttler, 1896). Employee turnover is an ongoing topic of research, especially in the area of public service, health care, hospitality and technology sectors (Decker et al., 2003; Fields, 2005; Davidson, 2006; Hatton et al., 2001). In this paper, the issues related to employee turnover and member's intentions to stay or leave were discussed contextualizing the topic to manufacturing sector. Employee turnover is defined as the influx and exists of individuals into and out of the workforce of an organization, over a specific period of time (Watkins, 1953).

\subsection{Factors Leading to Member's Decision to Stay or Leave}

\subsubsection{Reward}

Many factors are leading employee intention to leave from organization include hiring practice, managerial style, lack of recognition, and lack of competitive compensation system (Abbasi \& Hollman, 2000). Characteristics of 
firms, unemployment rates, and average age of employees, gender and racial composition are among other reasons causing employee turnover (Bennett, Terry, Blum, Long, \& Paul, 1993).

\subsubsection{Fairness at Workplace}

How employee looks at the organization and how they feel about the organizational justice is a factor that influence employees decisions stay or leave the organization which include employees' perceptions of fairness in their workplaces (Colquitt, Greenberg, \& Zapata-Phelan, 2005), fairness in the allocation of organizational rewards and resources among employees (Adams, 1965; Homans, 1961), the fairness of formal policies and procedures used in making those allocation decisions (Leventhal, 1980; Lind \& Tyler, 1988).

\subsubsection{Bullying and Harassment}

Bullying at work means harassing, offending, socially excluding someone or negatively affecting someone's work tasks. In order for the label bullying to be applied to a particular activity, interaction or process, the bullying behavior has to occur repeatedly and regularly and over a period of time. Bullying is an escalating process in the course of which the person confronted end up in an inferior position and becomes the target of systematic negative social acts (Einarsen, Hoel, Zapf, \& Cooper, 2011).

\subsubsection{Poor Management Relationship}

Employees are more likely to remain with an organization if they believe that their manager's shows interest and concern for them, if they know what all expected from them, if they have given a role that fits their capabilities and if they receive regular positive feedback and recognition. The quality of relationship an employee has with his or her immediate managers elongates employee stay in an organization (Ferreira, 2007; cited in Michael, 2008).

\subsubsection{Management Support}

Related empirical research has shown that high levels of Perceived Organizational Support (POS) to be associated with a host of positive work outcomes, including increased affective commitment (Eisenberger et al., 1990; Rhoades et al., 2001), reduced absenteeism and turnover intentions (Eisenberger et al., 1986; Eisenberger et al., 1990; Wayne et al., 1997).

\subsubsection{Supervisor}

Kottke and Sharafinski (1988) state that Perceived Supervisory Support (PSS) refers to employee views concerning the extent to which supervisor value employee's contributions, and care about their wellbeing. This indicates that, if employees perceive their supervisors as representatives of the organization (Eisenberger, et al., 1986; Levinson, 1965), they may develop exchange relationships with them that are distinct from those they experienced with their organization.

\subsubsection{Grievance Handling}

Ichiowski (1986) found that higher grievances were associated with lower plant productivity. Employee work related concerns and grievances, which are not promptly and effectively resolved, could lead to: lost productivity; lower quality work, products and customer services; distraction from corporate goals; loss of confidence and communication between employees, managers and supervisors; low morale, job satisfaction which can lead to industrial problems, increased absenteeism and increased staff turnover; loss of reputation to the employee; loss of reputation as an employer and service provider; lost working time of everyone involved in dealing with a complaint; and the potential for legal action and damages.

\subsubsection{Coworker Relationship}

Ivancevich and Matteson (1950) indicate, lack of group cohesiveness may explain various physiological and behavioural outcomes in an employ desiring such sticks together. Workplace interpersonal conflicts and negative interpersonal relations are prevalent sources of stress (Dewe, 1993; Lang, 1984), and are existed with negative mood depression, and symptoms of ill health (Israel et al., 1989; Karasek, Gardell, \& Lindell, 1987).

\subsubsection{Job Confirmation}

From the perspective of decent work, freedom of choice means that the worker possesses bargaining power and is able to negotiate with the employer about terms and conditions of employment without facing any punishment. In a situation of forced labor, the power of the employer to impose conditions and rules is absolute and the worker is unable to refuse without facing some kind of punishment, i.e. is under the menace of penalty. 'The issue at stake is the worker's ability to revoke the given consent and the premise that the worker's right to free choice of employment remains inalienable at any given point' (ILC, 2007) 


\subsubsection{Job Satisfaction}

High turnover and absenteeism is reported to be related to job dissatisfaction, while low absenteeism is associated with higher job satisfaction (Saifuddin, Hongkrailert, \& Sermsri, 2008). Specifically, Mobley (1977) theorized that job dissatisfaction likely leads an employee (1) to think about quitting, which may help that employee, (2) to evaluate the expected usefulness of searching for another job and the costs associated with quitting the current.

\subsubsection{Socialization}

When individuals enter into an organization, they re-evaluate their assumptions while seeking information to decrease uncertainty and anxiety, and easing these negative feelings is their main goal (Maanen \& Schein, 1979; Louis, 1980; Jones, 1986; Miller \& Jablin, 1991; Ashforth \& Saks, 1996).

\subsubsection{Management Style}

Gwavuya (2011) affirms that incompetent leadership results in poor employee performance, high stress, low job commitment, low job satisfaction and turnover intent.

\subsubsection{Wage and Salary}

Trevor, Gerhart and Boudreau (1997) observed that salary growth had a pronounced effect on turnover. Particularly, salary growth effects on turnover were greatest for high performers, that is, high salary growth significantly reduced turnover for high performing employees. The most common reason for employee turnover rate being so high is the salary scale because employees are usually in the search of well-paid jobs.

\subsubsection{Lack of Career Development}

Hellesey et al., (1985) identified limited career opportunity as a major factor in creating frustration and reduced motivation. Hellesey et al., (1985) identified limited career opportunity as a problem creating frustration and reduced motivation among workers.

\subsubsection{Workload}

French and Caplan (1972) observed that increased workload which causes high stress among employees and employers. The supervisors have a tendency to handover works to their subordinates. When the work exceeds the capabilities of an individual performing the work within the assigned time and resources, it creates role overload. French and Caplan (1973) suggest that both quantitative and qualitative overload produces many different symptoms in addition to psychological and physical strain.

\subsubsection{No Challenge}

Repetition at work is also another factor affecting the turnover intention. According to findings (Hackman \& Oldham, 1975) the more demanding the job, the more satisfaction it brings to an employee and this can potentially inspire an employee to work harder and the final productivity will be increased. In contrast, simple and routine jobs result in lower participation and higher absenteeism and consequently the higher desire to leave the job (Larson \& Laiken, 1999; Orpen, 1979).

\subsubsection{Rules and Regulations}

Quinn (1973) observed that, increased regulations on work environment produce increased dissatisfaction among employees. The organization functions are required to perform in a cooperative, cohesive and flexible way rather than rigid rules and orders. A study on the effect of stress on physical and emotional health, behavior and job performance found that stress reactions had appeared soon after the organization had undergone sweeping organizational change, itself a recognized sources of stress (Zaleznik et al., 1977). According to Lundbergh (2000) in the modern work environment physical hazards and demands have been reduced, whereas psychosocial stress caused by a very high work phase, competition and efficiency and by successive readjustment to organisational changes has increased. Changes in job content also may be sources of stress. Transfers, demotions and even promotions can be stressful. Seward states that stressful conditions are often produced when organizations undergo changes. The process of change may disrupt and individual equilibrium within an organization and place him at increased risk of a stress response.

\subsubsection{Shift Works}

Typically, humans are in a state of wakefulness during the daytime hours and resting or sleeping during the night hours. This behavior is regulated by the body's circadian rhythms (Costa, 1996). When the sleep cycle is adjusted to an earlier time of day than the normal night sleep times, it is referred to as an advanced circadian rhythm phase shift. An example of an advanced phase shift would be when workers sleep just prior to their night shift. 
An example of a phase delay is when sleep is postponed from the normal night/darkness sleep time to a time in the morning. (Costa, 1996). Some workers tolerate phase shifts better than others. For example, people commonly referred to as "night owls" normally go to bed later than others, so they delay their sleep. Adjustment to night work may not be as difficult for these people as for others (Burgess et al., 2002).

\subsubsection{Safety and Security}

Generally, health and safety at work are closely interrelated to ensure personal and material working conditions. Occupational hygiene refers to norms and procedures aimed at protecting workers' physical and mental integrity, protecting them against health risks inherent to the type of tasks of the job and to the physical environment where these tasks are executed. Safety at work consist of the technical, educational, medical and psychological measures used to prevent accidents, either by eliminating unsafe conditions within the environment or instructing or convincing workers of the need to introduce preventive practices (Aço, 1998).

\subsubsection{Health Facility}

According to Opatha (2003) health is a situation with non-existence of physical and psychological problems, which hinder the human general and special tasks and activities, and under employee safety, the precautions administered to avoid any potential hazard in a working environment. Poor psychological and physiological conditions result from organizational stress and a low quality of working life. These encompass dissatisfaction, withdrawal, projection, forgetfulness, inner confusion about roles and duties etc. (Schuler \& Jackson, 1996). Poor health condition forces employees to quit their job.

\subsubsection{Welfare Services and Turnover}

Priti (2009) argues that the role of welfare activities is to promote economic development by increasing efficiency and productivity with the underlying principle being made workers give their loyal services ungrudgingly in genuine spirit of co-operation and the general well-being of the employee. Despite this, Mwiti (2007) points out that naturally welfare services may not directly relate to an employee's job but the presence or absence of the services is notable through employee performance, attitude, and high or low labor turnover. It is argued that, welfare services can be used to secure the labor force by providing proper humane conditions of work and living through minimizing the hazardous effect on the life of the workers and their family members (Manzini \& Gwandure, 2011).

\subsubsection{Lack of Training and Development}

A lack of proper training and development is also a major cause for voluntary turnover. Employees prefer security of their jobs. (Carsten \& Spector, 1987). When evaluating the costs and benefits of training, workers and firms keep in mind the expected investment horizon, i.e. worker's turnover probability (Royalty, 1996).

\subsubsection{Location}

Masahudu (2008) has acknowledged other significant factors “"employers' geographic location" that may determine turnover. The closeness of employees with their families and significant others may be a reason to look elsewhere for opportunities or stay with their current employers. For instance, two families living and working across two time zones may decide to look for opportunities closer to each other.

\subsubsection{Ergonomics Issues}

Certain jobs or work conditions cause a higher rate worker complaints of undue strain, localized fatigue, discomfort, or pain that does not go away after an overnight rest. These types of jobs are often those involving activities such as repetitive and forceful exertions; frequent, heavy, or overhead lifts; awkward work positions; or use of vibrating equipment. (NIOSH, 2003). The Occupational Safety and Health Administration (OSHA, 2013) has found substantial evidence that ergonomics programs can cut workers' compensation costs, increase productivity and decrease employee turnover (Jeffress, 2013).

\section{Methedology}

In order to collect adequate information which support to answer this research question posed, and to develop an instrument that explore extensive study in this area, this particular study followed a mixed-methods approach, utilizing both quantitative and qualitative research methods. It is clearly pointed out by Ivankova et al., (2006) that when used in combination, quantitative and qualitative methods complement each other and allow for a more robust analysis, taking advantage of the strengths of each.

The theme of the research, related to 'member's intention stay back in organization'. In nutshell, the qualitative research method, was supported in identifying the variables that influence 'member's intention stay back in 
organization' and the quantitative method was supported in the generalization of the findings through the application of right statistical analysis with appropriate tools.

\subsection{Research Inquirey}

From the review of the literature, a conceptual understanding of factors leading a to members intention leave from organization is obtained. While, the question remains is, contextualising the topic to the manufacturing, how far these concepts and variables influence member's intention stay back in organization. By concentrating the study into manuufacturing companies in India this particular research tries to answer several questions like:

Which are the factors contributing to member's intention stay back in organization?

\subsubsection{Research Methodology: Qualitative}

Qualitative research is "an inquiry process of understanding" where the researcher develops a "complex, holistic picture, analyzes words, reports, detailed views of informants, and conducts the study in a natural setting" (Creswell, 1998). In qualitative research, data are collected from those immersed in everyday life of the setting in which the study is framed. Data analysis is based on the values that these participants perceive in their world. Ultimately, it "produces an understanding of the problem based on multiple contextual factors" (Miller, 2000). This particular study follows different qualitative research techniques to explore the topic under study. The study followed with available literature, case studies and Delphi technique that supported to crystallize the variables influence member's intention stay back in organization.

\subsubsection{Delphi Technique}

One of the qualitative methodologies of research followed in this study was Delphi technique has provided exploratory insight into the major variables closely knit with the concepts under study (Kumar, 2013). The Delphi technique is designed as a group communication process that aims at conducting detailed examinations and discussions of a specific issue for the purpose of goal setting, policy, investigation, or predicting the occurrence of future events (Ulschak, 1983; Turoff \& Hiltz, 1996; Ludwig, 1997). This research engaged semi-structured interviews. Based on the suitable time for the resource person interviews were arranged, during 2013 January to 2013 July. Telephonic interviews and direct interviews are conducted to gather information from the respondents. 40 experts from the industry and academia were identified and approached by email or telephone and were invited to take part in the study. All the clarifications related to the objective of the study were made by the researcher. However, 30 respondents were being interacted and communicated, only 20 respondents shown their willingness to participate in the discussion. Finally, 20 participants were interviewed by telephone and through email. The conversations tape recorded, and manually analyzed. The procedural steps in adopting the Delphi technique were as follows.

\subsubsection{Expert Panel Identification}

The group of professional gathered from specialists having high knowledge and expertise in providing information on variables that influence member's intention stay back in organization. The experts were closely associated with industries as consultants, Top-level HR managers, professors, researchers and academicians. The specialized areas of these expert members include, 16 male members $(80 \%)$ and 4 female members $(20 \%)$. These dynamic groups of panel of experts were knowledgeable and familiar to give relevant opinions and an admissible understanding of variables influence member's intention stay back in organization.

\subsubsection{Rounds}

Round 1

In the first round, the Delphi process traditionally begins with an open-ended questionnaire. The open-ended questionnaire serves as the cornerstone of soliciting specific information about a content area from the Delphi subjects (Custer, Scarcella, \& Stewart, 1999).

The questions:

1) How do you define member's intention stay back in organization?

2) How do you relate the variables 'member's intention stay back' in organization in various organizations?

3) Which are the major factors, in general closely related to member's intention stay back in organizations in manufacturing sector?

Round 2

In the second round, Delphi panelists may be required to rate or rank-order items to establish preliminary 
priorities among items. Because of round two, areas of disagreement and agreement were identified (Ludwig, 1994). Information regarding the influential factors of 'members intention to stay back' in manufacturing industries was collected from the respondents. The process identifies 161 categories, which are having items with high and low proximity of intention to stay or leave in the manufacturing industry was identified.

Round 3

In the third round, each Delphi panelist receives a questionnaire that includes the categories and items ratings, summarized by the investigators in the previous round and were asked to revise his/her judgments or "to specify the reasons for remaining outside the consensus" (Pfeiffer, 1968). This round gives Delphi panelists an opportunity to make further clarifications of both the information and their judgments about the relative importance of the categories and items. Second levels screening of the 161 categories, which have a high and low influence on intention to stay or leave in the manufacturing industries, were identified with corresponding items. The process further identified 89 categories, which were having high and low proximity of the 'members' intention to stay back'. Classification of the items in 89 categories of 7 factors was being made with appropriate loaded items. Thematic presentation and the categorization of the items were done.

\section{Round 4}

In the fourth and often final round, the list of remaining items, their ratings, minority opinions, and items achieving consensus, were distributed to the panelists. This round provides a final opportunity for participants to revise their judgments. It should be remembered that the number of Delphi iterations depends largely on the degree of consensus sought by the investigators and can vary from three to five (Ven \& Gustafson, 1975; Ludwig, 1994). During third level, screening of the 83 categories which have items with high and moderately high proximity of member's intention stay back in organization in manufacturing industry was identified. Further, sought the expert opinion on the appropriateness of the core factors selected for the study.

\subsubsection{Results Qualitative}

Table 1. Member's intention stay back in organization: Delphi application

\begin{tabular}{|c|c|c|c|c|c|}
\hline $\begin{array}{l}\text { No: } \\
\text { S/N }\end{array}$ & Intention to leave Factors & Categories & $\begin{array}{l}\text { No. } \\
\text { Items }\end{array}$ & $\begin{array}{l}\begin{array}{l}\text { No of } \\
(\mathrm{N}=20)\end{array} \\
\end{array}$ & $\begin{array}{l}\text { \% } \\
\text { Experts }\end{array}$ \\
\hline \multirow{4}{*}{1} & \multirow{4}{*}{ Career Promotion } & Career Plan & 2 & 17 & $85 \%$ \\
\hline & & Career Opportunities & 2 & 17 & $85 \%$ \\
\hline & & Level Career Orientation & 2 & 18 & $90 \%$ \\
\hline & & Career Hope & 1 & 18 & $95 \%$ \\
\hline \multirow{4}{*}{2} & \multirow{4}{*}{ Reward Management } & Salary/Wage & 2 & 18 & $90 \%$ \\
\hline & & Perks and commission & 2 & 17 & $85 \%$ \\
\hline & & Bonus & 1 & 17 & $85 \%$ \\
\hline & & Allowances & 2 & 17 & $75 \%$ \\
\hline \multirow{2}{*}{3} & \multirow{2}{*}{ Training \& Development } & Opportunity for Professional Development & 2 & 17 & $85 \%$ \\
\hline & & Opportunity for Personal Development & 3 & 17 & $85 \%$ \\
\hline \multirow{4}{*}{4} & \multirow{4}{*}{ Management Style } & Leadership Style & 2 & 17 & $85 \%$ \\
\hline & & Employee orientation & 2 & 16 & $80 \%$ \\
\hline & & Work Orientation & 2 & 17 & $85 \%$ \\
\hline & & Organizational Support & 1 & 15 & $75 \%$ \\
\hline \multirow{4}{*}{5} & \multirow{4}{*}{ Insufficient Challenge } & Variety & 2 & 16 & $80 \%$ \\
\hline & & Innovation & 2 & 17 & $85 \%$ \\
\hline & & Experimentation & 2 & 17 & $85 \%$ \\
\hline & & Skill enhancement opportunity & 2 & 16 & $80 \%$ \\
\hline \multirow{6}{*}{6} & \multirow{6}{*}{ Conditions of Service } & Terms and conditions & 2 & 15 & $75 \%$ \\
\hline & & Rigid rules and regulation & 2 & 16 & $80 \%$ \\
\hline & & Feeling of Insecurity & 2 & 17 & $85 \%$ \\
\hline & & Lack of Interest & 3 & 16 & $80 \%$ \\
\hline & & Detachment from work & 3 & 17 & $85 \%$ \\
\hline & & Detachment from organization & 3 & 17 & $85 \%$ \\
\hline
\end{tabular}




\begin{tabular}{|c|c|c|c|c|c|}
\hline $\begin{array}{l}\text { No: } \\
\text { S/N }\end{array}$ & Intention to leave Factors & Categories & $\begin{array}{l}\text { No. } \\
\text { Items }\end{array}$ & $\begin{array}{l}\text { No of Experts } \\
(\mathrm{N}=\mathbf{2 0})\end{array}$ & $\begin{array}{l}\% \\
\text { Experts }\end{array}$ \\
\hline \multirow{6}{*}{7} & \multirow{6}{*}{ Flexibility in Working Hours } & Detachment between colleague & 3 & 15 & $75 \%$ \\
\hline & & Rigid working hours & 2 & 17 & $85 \%$ \\
\hline & & Long working hours & 3 & 16 & $80 \%$ \\
\hline & & Over work & 3 & 16 & $80 \%$ \\
\hline & & Lack of rest & 3 & 16 & $80 \%$ \\
\hline & & Lack of support activities among colleague & 3 & 15 & $75 \%$ \\
\hline \multirow{4}{*}{8} & \multirow{4}{*}{ Work condition } & Issue on Physical health & 2 & 16 & $80 \%$ \\
\hline & & Hazardous Chemical Use & 2 & 15 & $75 \%$ \\
\hline & & Long standing work & 2 & 15 & $75 \%$ \\
\hline & & Lack of rest & 2 & 15 & $75 \%$ \\
\hline \multirow{3}{*}{9} & \multirow{3}{*}{ Location } & Long journey to reach at work & 2 & 16 & $80 \%$ \\
\hline & & No transport facility from organization & 2 & 15 & $75 \%$ \\
\hline & & No frequent transport facility in general & 2 & 16 & $80 \%$ \\
\hline \multirow{3}{*}{10} & \multirow{3}{*}{ Health Facilities } & No medical facility & 2 & 16 & $80 \%$ \\
\hline & & Long distance to access medical facility & 2 & 15 & $75 \%$ \\
\hline & & Neglect from management & 2 & 16 & $80 \%$ \\
\hline \multirow{5}{*}{11} & \multirow{5}{*}{$\begin{array}{l}\text { Nature of Work } / \text { Job } \\
\text { Satisfaction }\end{array}$} & Repetitive work (monotonous) & 2 & 16 & $80 \%$ \\
\hline & & No multi skilling & 2 & 15 & $75 \%$ \\
\hline & & No challenge & 2 & 16 & $80 \%$ \\
\hline & & Lack of variety & 3 & 16 & $80 \%$ \\
\hline & & No enthusiasm & 3 & 16 & $80 \%$ \\
\hline \multirow{5}{*}{12} & \multirow{5}{*}{ Differential treatment } & $\begin{array}{l}\text { Discrimination on local and foreign } \\
\text { workers }\end{array}$ & 2 & 15 & $75 \%$ \\
\hline & & Discrimination in wages & 2 & 15 & $75 \%$ \\
\hline & & Discrimination in welfare facilities & 2 & 17 & $85 \%$ \\
\hline & & $\begin{array}{l}\text { Discrimination } \\
\text { confirmation }\end{array}$ & 3 & 17 & $85 \%$ \\
\hline & & $\begin{array}{l}\text { Discrimination among male and female } \\
\text { employees }\end{array}$ & 3 & 15 & $75 \%$ \\
\hline \multirow{2}{*}{13} & \multirow{2}{*}{ Heavy Workload } & Overload & 2 & 15 & $75 \%$ \\
\hline & & Difficulty in performing work & 2 & 15 & $80 \%$ \\
\hline \multirow{4}{*}{14} & \multirow{4}{*}{$\begin{array}{l}\text { Poor relationship with } \\
\text { co-workers }\end{array}$} & Lack of co-worker support & 2 & 15 & $85 \%$ \\
\hline & & Individual orientation & 2 & 15 & $80 \%$ \\
\hline & & No team work & 2 & 16 & $80 \%$ \\
\hline & & Lack of cooperation & 2 & 15 & $75 \%$ \\
\hline \multirow{5}{*}{15} & \multirow{5}{*}{$\begin{array}{l}\text { Poor relationship with } \\
\text { supervisors }\end{array}$} & Lack of supervisory support & 2 & 15 & $75 \%$ \\
\hline & & High task orientation & 3 & 17 & $85 \%$ \\
\hline & & Punishment oriented & 3 & 17 & $85 \%$ \\
\hline & & Fearful relation & 3 & 15 & $75 \%$ \\
\hline & & Blame game & 3 & 15 & $75 \%$ \\
\hline \multirow{4}{*}{16} & \multirow{4}{*}{$\begin{array}{l}\text { Lack of } \\
\text { recognition }\end{array}$} & Monotonous job & 2 & 16 & $80 \%$ \\
\hline & & Low level innovation & 2 & 16 & $80 \%$ \\
\hline & & Low level experimentation & 2 & 15 & $75 \%$ \\
\hline & & No recognition at work & 1 & 15 & $75 \%$ \\
\hline \multirow{3}{*}{17} & \multirow{3}{*}{$\begin{array}{l}\text { Lack of } \\
\text { management }\end{array}$} & Poor support from top management & 2 & 15 & $75 \%$ \\
\hline & & Lack of involvement of top management & 2 & 16 & $80 \%$ \\
\hline & & Neglect from top management & 2 & 15 & $80 \%$ \\
\hline & & Confusing Job Description & 2 & 15 & $75 \%$ \\
\hline 18 & No Job Description & Role conflict & 2 & 16 & $80 \%$ \\
\hline & & Lack of information sharing & 2 & 15 & $80 \%$ \\
\hline
\end{tabular}




\begin{tabular}{|c|c|c|c|c|c|}
\hline $\begin{array}{l}\text { No: } \\
\text { S/N }\end{array}$ & Intention to leave Factors & Categories & $\begin{array}{l}\text { No. } \\
\text { Items }\end{array}$ & $\begin{array}{l}\text { No of Experts } \\
(\mathrm{N}=20)\end{array}$ & $\begin{array}{ll}\% & \text { of } \\
\text { Experts } & \end{array}$ \\
\hline \multirow{6}{*}{19} & \multirow{6}{*}{$\begin{array}{l}\text { Delay in employment } \\
\text { confirmation }\end{array}$} & No role authority & 3 & 16 & $80 \%$ \\
\hline & & Long probation & 2 & 15 & $75 \%$ \\
\hline & & Delay in job confirmation & 2 & 16 & $80 \%$ \\
\hline & & Delay in getting full wage & 2 & 15 & $80 \%$ \\
\hline & & Delay in getting monetary benefits & 3 & 16 & $80 \%$ \\
\hline & & Less safety facilities & 2 & 15 & $75 \%$ \\
\hline \multirow{2}{*}{20} & \multirow{2}{*}{ Safety } & Less safety equipments & 2 & 16 & $80 \%$ \\
\hline & & No standard safety equipments & 2 & 15 & $75 \%$ \\
\hline \multirow{7}{*}{21} & \multirow{7}{*}{ Ergonomics Issues } & Poor safety environment & 1 & 15 & $75 \%$ \\
\hline & & Continuous standing & 2 & 15 & $75 \%$ \\
\hline & & No option to get rest & 2 & 15 & $75 \%$ \\
\hline & & Physical illness & 2 & 16 & $80 \%$ \\
\hline & & Stress and Strain & 2 & 15 & $75 \%$ \\
\hline & & $\begin{array}{l}\text { Dusty environment within the section } \\
\text { affect others }\end{array}$ & 2 & 15 & $75 \%$ \\
\hline & & $\begin{array}{l}\text { Strong paint smell circulated to all } \\
\text { area/section }\end{array}$ & 2 & 16 & $80 \%$ \\
\hline
\end{tabular}

\subsubsection{Quantitative Research Method}

For the purpose of data analyses and hypothesis testing, several statistical tools and methods employed using SPSS software version 17. These include reliability and factor analyses to test the goodness of measures.

\subsubsection{Validity and Reliability}

Validity is the ability of a tool to measure what is supposed to measure. The validity of an instrument is the degree to which an instrument measures what it is intended to measure (Polit \& Hungler, 1993). Validity tests, then compare and measure the concept that a researcher supposed measure with its accuracy. Precisely the degree to which an instrument used by the researcher measures what he/she intended to measure. It is expected that the instrument should ensure content, construct and face validity.

\subsubsection{Dealing the Content Validity}

The objective of this phase was to get the agreements of experts on the concept, constructs and content of the items selected in the draft 'intention stay back in organization'. To get the content validity, in addition to the literature review, the study was incorporated triangulation method of qualitative research in which expert identification of the variables that selected under organizational and individual factors related to 'intention stay back in organization' were made. The Delphi technique, content analysis, and short case study method followed thorough interviews and discussion techniques supported the researchers to ensure content validity of the variables considered for the study. Especially, the Delphi Technique followed in the research was supported to get the right content of each item that incorporated in the each factor. Thus, in general, the constructs and the content of the items were agreed upon with the correction and consent from the experts. Based on their comments on each parameter and items rewording of the items were made which was further fine-tuned for development of the instrument.

\subsubsection{Dealing the Face Validity}

The study further ensured face validity by examining the instrument looks as though it is measuring what it was supposed to measure. Face validity is a necessary procedure in any instrument development process (Benson \& Clark, 1983). To get the face validity, experts in the field of management and human resources areas, statisticians, and academicians were identified. Thus the experts in the field of management and human resources areas, statisticians, and academicians were cross verified the face validity of the instrument. To end with, the construction of the items based on the concepts of the constructs, sub-constructs that developed out of the literature review and case interviews, was made. It was pointed out by the experts that in order to develop these items into an instrument mode, factor analysis to be conducted in the later stage. It was also suggested by the experts that the item's length, which was observed during the Delphi technique to be shortened before factor analysis application that ensure better understanding to the respondents. 


\subsubsection{Dealing the Construct Validity}

To test the construct validity the instrument is well correlated to the underpinning theories, motivation, leadership, job satisfaction, absenteeism, attrition, retention, work stress, work culture, organizational climate, theory of planned behavior, theory of reasoned action etc., which were closely knit with the concept organizational factors and individual factors in relation to member's 'intention stay back in the organization'. Validation of the instrument and the concept both were done on factors related to members 'intention stay back in organization'. Herzberg's Two Factor Theory (1959) was confirmed by the researcher and experts that closely knit with the concepts, variables and items incorporated in the study.

\subsubsection{Factor Analysis and Reliability Test}

Prior to any validity and reliability tests, the tests of assumptions for multivariate analysis will be conducted to ensure that the data met the normality, linearity, multicollinearity, and homoscedasticity assumptions. The next important step in data analysis is to understand the dimension of the variables in the proposed framework or relationships posited in empirical research (Hair et al., 2010). In other words, factor analysis should be performed to identify the structure of interrelationship among a large number of items in the study. This may be done by defining common underlying dimensions, commonly known as factor (Hair et al., 2010). Another purpose for performing factor analysis is to determine whether the data could be condensed or summarized into smaller set of factors (Malhotra, 2010). The dimensions of the scale were examined by factor analyzing the items using the principal components analysis with Varimax rotation. Minimum eigenvalues of 1.0 helped determine the number of factors or dimensions for each scale (Hair et al., 2010). Although factor loadings of 0.30 to 0.40 are considered acceptable, however, factor loadings greater than 0.50 are generally necessary for the practical significance (Hair et al., 2010). Hence, the items for a factor will be retained only when the absolute size of their factor loading is above 0.50 .

To test the internal consistency of the measurement, reliability analysis is performed on the factors extracted using the benchmark suggested by Nunnally (1978). Generally, the closer reliability score gets to 1.0, the more reliable the scale would be. According to Nunnally (1978), the reliability score of 0.70 and above is acceptable and those above 0.80 are considered good. As noted by Peter (1979), reliability scores that less than 0.60 is still considered acceptable for social science studies. Following the literature, a reliability score of 0.70 is used as the benchmark for this study. It should be noted that all the negatively worded items in the questionnaire were first being reversed coded prior to the reliability test. In the case of coefficient alpha value is smaller than 0.70 , the item with the lowest corrected item-to-total correlation is removed until then 0.70 levels are met (Pallant, 2001).

\subsubsection{Ethical Considerations}

In both the phases, the ethical considerations were well followed by the researches due to the sensitive issues related to the topic. This sensitivity is perceived from a 'management' point of view as well as 'member's' perspective. Both parties aspired to ensure their anonymity during all stages of research. The employees were assured that the summary data would be disseminated to the management, but in no way the responses of them can be identified. It is also assured that the data will be destroyed keeping the documents after a reasonable period. Instead of the names of the member's the data coded with numbers to ensure the anonymity both in case studies as well as quantitative data collection procedures.

Table 2. Items, theoretical range and Cronbach Alpha-intention to stay instrument

\begin{tabular}{lllll}
\hline Sl. No & Factors & No of Items & Theoretical Range & Standardized Alpha \\
\hline 1 & Career Advancement & 4 & $4-40$ & .800 \\
2 & Reward Management & 4 & $4-40$ & .790 \\
3 & Training \& Development & 4 & $4-40$ & .801 \\
4 & Management Style & 3 & $3-30$ & .803 \\
5 & Insufficient Challenge & 4 & $4-40$ & .792 \\
6 & Terms and Conditions & 4 & $4-40$ & .796 \\
7 & Working Hours/Shift & 4 & $4-40$ & .791 \\
8 & Work Condition & 3 & $3-30$ & .810 \\
9 & Health Facilities & 2 & $2-20$ & .804 \\
10 & Nature of Work & 4 & $4-40$ & .780 \\
11 & Heavy Workload & 4 & $4-40$ & .821 \\
\hline
\end{tabular}




\begin{tabular}{lllll}
\hline Sl. No & Factors & No of Items & Theoretical Range & Standardized Alpha \\
\hline 12 & Relationship with Co-workers & 4 & $4-40$ & .804 \\
13 & Relationship with Supervisors & 4 & $4-40$ & .789 \\
14 & Achievement Recognition & 4 & $4-40$ & .806 \\
15 & Supportive Management & 3 & $3-30$ & .799 \\
16 & Socialization & 4 & $4-40$ & .835 \\
17 & Employment Confirmation & 2 & $2-20$ & .804 \\
18 & Location & 4 & $4-40$ & .776 \\
19 & Target Orientation & 3 & $3-30$ & .812 \\
20 & Safety & 4 & $4-40$ & .815 \\
21 & Ergonomics & 4 & $4-40$ & .821 \\
\hline
\end{tabular}

\subsubsection{Reliability}

Reliability means the consistency or repeatability of the measure and the confidence we can place on the measuring instrument to give the same numeric value when the measurement will be repeated on the same subject. The purpose of this procedure was to determine which items should be retained and which items should be dropped based on the values of the Cronbach Alpha (Creswell, 2008; J. P. Gall \& M. D. Gall, 1998). A reliable instrument is one that would provide the identical results if used recurrently by the same group.

When the researcher started qualitative research through interviews, case studies and field observation, the researchers were developed well, acquaintances with the employees working in the organization. By ensuring adequate privacy to the employees in the organizational environment, the researchers were ensured better physical and psychological environment for data collection.

\subsubsection{Dealing the Item's Reliability}

The study follows three stages. In the initial stage, the study considered 91 items under 21 factors and subjected to pilot testing with thirty respondents from the organization. A bipolar interval scale was used representing with 1 as 'Strongly Disagree' and 10 representing 'Strongly Agree'. The instrument retained the same order of response categories to minimize confusion amongst respondents. Later, with due consideration to the Cronbach Alpha values of each item in the draft instrument, some of the items, which were having less than 0.5 dropped and others were gathered into. A 10-point interval scale with 76 items was finally considered.

\subsubsection{Managing the Standardization Process}

In order to establish the standardization process, five companies in the large-scale manufacturing process identified. To make a comparative analysis five groups of workers was selected with a size of 40 members from each company. These companies are located far from each other to ensure the representation from different places with different products. Further, an instrument of 76 items and 10 point interval scale scales were administered into these five groups. It was observed that the Cronbach Alpha values of the items remained almost the same. Based on the inference it is further inferred that this instrument is highly reliable to be used on any working group belong to large-scale industrial organizations in the manufacturing sector. Table 1 show that the values of the Cronbach alpha of the constructs for the five different groups when compared were more or less the same.

Table 3. Member's intention to stay among five groups: Factor analysis procedure

\begin{tabular}{|c|c|c|c|c|c|c|c|}
\hline SI. No & Constructs & $\begin{array}{l}\text { Cronbach Aplha (\% Point } \\
\text { Likert Scale) }\end{array}$ & $\begin{array}{l}\text { Work } \\
\text { Group } 1\end{array}$ & $\begin{array}{l}\text { Work } \\
\text { Group } 2\end{array}$ & $\begin{array}{l}\text { Work } \\
\text { Group } 3\end{array}$ & $\begin{array}{l}\text { Work } \\
\text { Group } 4\end{array}$ & $\begin{array}{l}\text { Work } \\
\text { Group } 5\end{array}$ \\
\hline 1 & Career Advancement & .800 & .801 & .792 & .803 & .809 & .811 \\
\hline 2 & Reward Management & .790 & .799 & .790 & .800 & .789 & .836 \\
\hline 3 & $\begin{array}{l}\text { Training \& } \\
\text { Development }\end{array}$ & .801 & .831 & .798 & .800 & .821 & .836 \\
\hline 4 & Management Style & .803 & .830 & .744 & .819 & .822 & .780 \\
\hline 5 & Insufficient Challenge & .792 & .800 & .780 & .830 & .803 & .789 \\
\hline 6 & Terms and Conditions & .796 & .800 & .803 & .817 & .791 & .811 \\
\hline 7 & Working Hours/Shift & .791 & .830 & .837 & .780 & .833 & .799 \\
\hline
\end{tabular}




\begin{tabular}{|c|c|c|c|c|c|c|c|}
\hline Sl. No & Constructs & $\begin{array}{l}\text { Cronbach Aplha (\% Point } \\
\text { Likert Scale) }\end{array}$ & $\begin{array}{l}\text { Work } \\
\text { Group } 1\end{array}$ & $\begin{array}{l}\text { Work } \\
\text { Group } 2\end{array}$ & $\begin{array}{l}\text { Work } \\
\text { Group } 3\end{array}$ & $\begin{array}{l}\text { Work } \\
\text { Group } 4\end{array}$ & $\begin{array}{l}\text { Work } \\
\text { Group } 5\end{array}$ \\
\hline 8 & Work condition & .810 & .794 & .800 & .812 & .809 & .815 \\
\hline 9 & Health facilities & .804 & .811 & .712 & .823 & .780 & .808 \\
\hline 10 & Nature of Work & .780 & .821 & .806 & .792 & .809 & .803 \\
\hline 11 & Heavy Workload & .821 & .816 & .765 & .833 & .831 & .829 \\
\hline 12 & $\begin{array}{l}\text { Relationship with } \\
\text { co-workers }\end{array}$ & .804 & .841 & .800 & .815 & .826 & .799 \\
\hline 13 & $\begin{array}{l}\text { Relationship with } \\
\text { supervisors }\end{array}$ & .789 & .770 & .800 & .820 & .808 & .800 \\
\hline 14 & $\begin{array}{l}\text { Achievement } \\
\text { recognition }\end{array}$ & .806 & .806 & .780 & .799 & .812 & .822 \\
\hline 15 & $\begin{array}{l}\text { Supportive } \\
\text { management }\end{array}$ & .799 & .831 & .779 & .780 & .819 & .809 \\
\hline 16 & Socialization & .835 & .840 & .808 & .808 & .789 & .826 \\
\hline 17 & $\begin{array}{l}\text { Employment } \\
\text { confirmation }\end{array}$ & .804 & .800 & .811 & .777 & .799 & .841 \\
\hline 18 & Location & .776 & .747 & .801 & .799 & .800 & .810 \\
\hline 19 & Target Orientation & .812 & .804 & .794 & .768 & .742 & .801 \\
\hline 20 & Safety & .815 & .850 & .856 & .800 & .814 & .789 \\
\hline 21 & Ergonomics & .821 & .809 & .824 & .812 & .819 & .814 \\
\hline
\end{tabular}

\subsubsection{Factor Analysis Procedure}

The study intended to measure members' 'Intention Stay Instrument' (ISI) and the second instrument is 'finally' (ILI). Henceforth, the ultimate phase of this process of developing the instruments was to conduct the factorial analysis procedure on this draft instrument and 10-point scales. The objective of doing factorial analysis was to ascertain whether the items for each construct really fit in constructs. This procedure informs which items should be excluded or included with one construct. This was done by measuring the correlation values between the items within the given constructs.

\subsubsection{Factorial Analysis Results for Items Rejected in Each Construct}

Further, during the factor analysis, those items that were scored 0.5 and below were automatically rejected. Initially, the draft questionnaire was consisted of 91 items. The total number of items rejected based on the draft instrument with 91 items and 10 point interval scales were 14. The total variance explained for all the factors under consideration in the study is 0.698 . The final instrument after rejecting the items, which were scored more than 0.5 under 21 sub-variables of major variable 'intention to stay' further mentioned below.

Table 4. Items for the variables and factor analysis-member's intention to stay

\begin{tabular}{llllll}
\hline Factors and Item no & Factor Loading & $\boldsymbol{\alpha}$ & Eigine Value & Explain Variance (\%) & Total Explain Variance (\%) \\
\hline Career Advancement & & & & \\
C1 & .800 & & & \\
C2 & .821 & $\mathbf{8 0 0}$ & $\mathbf{1 . 6 9 9}$ & $\mathbf{6 . 9 1 6}$ \\
C3 & .801 & & & \\
C4 & .805 & & & \\
Reward Management & & & & \\
R5 & .799 & & & \\
R6 & .860 & $\mathbf{. 7 9 0}$ & $\mathbf{1 . 6 4 8}$ & $\mathbf{5 . 9 9 9}$ \\
R7 & .854 & & & \\
R8 & .849 & & & \\
Training \& Development & .801 & & & \\
T9 & .811 & $\mathbf{. 8 0 1}$ & $\mathbf{1 . 5 5 7}$ & $\mathbf{5 . 9 9 0}$ \\
T10 & .812 & & \\
T11 & & & \\
\hline
\end{tabular}




\begin{tabular}{|c|c|c|c|c|c|}
\hline Factors and Item no & Factor Loading & $\alpha$ & Eigine Value & Explain Variance (\%) & Total Explain Variance (\%) \\
\hline T12 & .780 & & & & \\
\hline \multicolumn{6}{|l|}{ Management Style } \\
\hline M13 & .856 & \multirow{3}{*}{.803} & \multirow{3}{*}{1.556} & \multirow{3}{*}{4.810} & \\
\hline M14 & .859 & & & & \\
\hline M15 & .848 & & & & \\
\hline \multicolumn{6}{|l|}{ Insufficient Challenge } \\
\hline I16 & .821 & \multirow{4}{*}{.792} & \multirow{4}{*}{1.552} & \multirow{4}{*}{4.781} & \\
\hline $\mathrm{I} 17$ & .828 & & & & \\
\hline $\mathrm{I} 18$ & .791 & & & & \\
\hline I19 & .819 & & & & \\
\hline \multicolumn{6}{|l|}{ Terms and Conditions } \\
\hline TC20 & .831 & \multirow{4}{*}{.796} & \multirow{4}{*}{1.510} & \multirow{4}{*}{3.610} & \\
\hline $\mathrm{TC} 21$ & .840 & & & & \\
\hline $\mathrm{TC} 22$ & .843 & & & & \\
\hline $\mathrm{TC} 23$ & .819 & & & & \\
\hline \multicolumn{6}{|l|}{ Working Hours/Shift } \\
\hline $\mathrm{TC} 24$ & .861 & \multirow{4}{*}{.791} & \multirow{4}{*}{1.499} & \multirow{4}{*}{3.609} & \\
\hline $\mathrm{TC} 25$ & .866 & & & & \\
\hline $\mathrm{TC} 26$ & .852 & & & & \\
\hline $\mathrm{TC} 27$ & .851 & & & & \\
\hline \multicolumn{6}{|l|}{ Work Condition } \\
\hline W28 & .821 & \multirow{3}{*}{.810} & \multirow{3}{*}{1.478} & \multirow{3}{*}{3.608} & \\
\hline W29 & .793 & & & & \\
\hline W30 & .830 & & & & \\
\hline \multicolumn{6}{|l|}{ Health Facilities } \\
\hline H31 & .796 & 804 & 1470 & 2607 & \\
\hline H32 & .860 & .804 & $1.4 / 0$ & $5.00 /$ & \\
\hline Nature of Work & & & & & \\
\hline N33 & .856 & & & & \\
\hline N34 & .859 & 780 & 140 & 5545 & \\
\hline N35 & .861 & .100 & 1.409 & 2.345 & \\
\hline N36 & .866 & & & & \\
\hline Heavy Workload & & & & & \\
\hline N37 & .820 & & & & \\
\hline N38 & .819 & 009 & 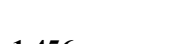 & -1 & \\
\hline N39 & .816 & .821 & 1.456 & 2.543 & \\
\hline $\mathrm{N} 40$ & .797 & & & & \\
\hline Relationship With Co & orkers & & & & \\
\hline R41 & .800 & & & & \\
\hline R42 & .803 & & & & \\
\hline $\mathrm{R} 43$ & .807 & .804 & 1.452 & 2.400 & \\
\hline R44 & .811 & & & & 69.981 \\
\hline Relationship With Su & jisors & & & & \\
\hline RS45 & .816 & & & & \\
\hline RS46 & .822 & 780 & 1450 & 210 & \\
\hline RS47 & .829 & .789 & 1.450 & 2.319 & \\
\hline RS48 & .800 & & & & \\
\hline Achievement Recogni & & & & & \\
\hline A49 & .800 & & 1440 & 210 & \\
\hline A50 & .802 & .806 & 1.448 & 2.318 & \\
\hline
\end{tabular}




\begin{tabular}{|c|c|c|c|c|c|}
\hline Factors and Item no & Factor Loading & $\alpha$ & Eigine Value & Explain Variance (\%) & Total Explain Variance (\%) \\
\hline A51 & .804 & & & & \\
\hline A52 & .787 & & & & \\
\hline \multicolumn{6}{|c|}{ Supportive Management } \\
\hline S53 & .833 & \multirow{3}{*}{.799} & \multirow{3}{*}{1.442} & \multirow{3}{*}{2.221} & \\
\hline S54 & .832 & & & & \\
\hline S55 & .836 & & & & \\
\hline \multicolumn{6}{|l|}{ Socialization } \\
\hline HS56 & .799 & \multirow{4}{*}{.835} & \multirow{4}{*}{1.440} & \multirow{4}{*}{2.220} & \\
\hline HS57 & .809 & & & & \\
\hline HS58 & .789 & & & & \\
\hline HS59 & .818 & & & & \\
\hline \multicolumn{6}{|c|}{ Employment Confirmation } \\
\hline EC60 & .801 & \multirow{2}{*}{.804} & \multirow{2}{*}{1.398} & \multirow{2}{*}{2.214} & \\
\hline EC61 & .821 & & & & \\
\hline \multicolumn{6}{|l|}{ Location } \\
\hline L62 & .800 & \multirow{4}{*}{.776} & \multirow{4}{*}{1.394} & \multirow{4}{*}{2.210} & \\
\hline L63 & .802 & & & & \\
\hline L64 & .792 & & & & \\
\hline L65 & .803 & & & & \\
\hline \multicolumn{6}{|l|}{ Target Orientation } \\
\hline TO66 & .850 & \multirow{3}{*}{.812} & \multirow{3}{*}{1.391} & \multirow{3}{*}{2.100} & \\
\hline TO67 & .852 & & & & \\
\hline TO68 & .790 & & & & \\
\hline \multicolumn{6}{|l|}{ Safety } \\
\hline SF69 & .805 & \multirow{4}{*}{.815} & \multirow{4}{*}{1.390} & \multirow{4}{*}{1.988} & \\
\hline SF70 & .809 & & & & \\
\hline SF71 & .813 & & & & \\
\hline SF72 & .819 & & & & \\
\hline \multicolumn{6}{|l|}{ Ergonomics } \\
\hline E73 & .811 & \multirow{4}{*}{.821} & \multirow{4}{*}{1.298} & \multirow{4}{*}{1.973} & \\
\hline E74 & .821 & & & & \\
\hline E75 & .832 & & & & \\
\hline E76 & .825 & & & & \\
\hline
\end{tabular}

\section{Interpretation of the Index Level of Member's Intention to Stay}

\subsection{High Scores: At the Highest Level}

High scores: A self-rating score within this range indicates the 'member's intention to stay back in the organization'. This means he/she having well appreciation towards the organization management and work environment. The work values are highly appreciated and the members integrate themselves with the organization. The members have the feeling that the organization meets their personal as well as professional goals by staying in the organization.

\section{Suggestion proposed}

If an employee scored within this range, the management should take appropriate steps to retain their happiness and satisfaction with the organization by ensuring more opportunities. Maintaining a happy employee is too difficult task, especially those who have a high impression towards the organization and they are the strongest supporters of the organization's visibility and image. This scenario will contribute more 'integration' rather 'member's intention to stay leave from the organization'.

\subsection{Moderate Scores: At the Moderate Level}

Moderate scores: A self-rating score within this range indicates the employees feeling of moderate level satisfaction with the organization. This means he/she has a moderate level appreciation towards the organization 
management and work environment. The work values are moderately appreciated and the employees moderately integrate themselves with the organization. The employees have the feeling that the organization moderately meets their personal as well as professional goals, by staying in the organization.

\section{Suggestion proposed}

If an employee scored within this range, the management should take appropriate steps to retain their happiness and job satisfaction by determining their dissatisfying factors. Care should be taken that in the long term these moderate level satisfaction factors may lead to member's intention to leave from the organization. This will affect the visibility and image of the organization in the long run. Appropriate steps need to be taken by the organization management in order to enhance member's level of satisfaction.

\subsection{Low Scores: At the Low Level}

Low scores: A self-rating score within this range indicates the employees feeling of low satisfaction level within the organization. This means that he/she has a low level appreciation towards the organization management and work environment. The work values are less appreciated and the employees seldom integrate themselves with the organization. The employees have the feeling that the organization rarely meets their personal as well as professional goals, even if they take decision to stay back the organization.

\section{Suggestion proposed}

If an employee scored within this range, the management should take appropriate steps to retain their happiness and job satisfaction by determining their dissatisfying factors. In the long run these low level satisfaction factors may lead to high level of 'member's intention to leave from the organization'. Further, this will affect the visibility and image of the organization. Appropriate steps need to be taken into consideration by the organization management to enhance their level of integration.

\section{Conclusion}

Attrition is widely rampant in many manufacturing organization due to varied organizational and individual factors. To a certain extend 'member's intention to stay back in the organization' is related to many key organizational behavior and management domain like, motivation, leadership, organizational culture, work ethics, employee relations, organizational policies, organizational commitment etc., like several individual and organizational factors. However, these factors are varying from one organization to another organization and from one region several organizational and individual factors. Identification of these factors and prevent the negative consequences of such factors are the role expected by the top management from the Human Resource Professionals. This instrument thus paves a better insight into the integrated factors of attrition, which answers why an employee want to stay back in the organization. The reliability analysis was done in the Indian context. This instrument's validity and reliability further need to be empirically observed in various countries for its better standardization and generalization.

\section{Acknowledgements}

This research paper has its origin from the research project funded and supported by Othman Yeop Abdullah Graduate School of Business (OYAGSB), Universiti Utara Malaysia, Sintok, Kedah, Malaysia. The researchers express their sincere gratitude to the Dean of OYAGSB, on his constant support in the accomplishment of this project further its dissemination to the research and academic world to get its wider applicability.

\section{References}

Abercrombie, N. H. T. S., \& Bryan, S. (1984). Dictionary of Sociology. Harmondsworth: Penguin.

Aço, S. (1998). Administration and management of human resources. Professional Training. Didactic material. Luanda: Emosist.

Adam, J. S. (1965). Inequity in social exchange. In L. Berkowitz (Ed.), Advances in experimental social psychology (Vol. 2, pp. 267-299). New York, NY: Academic Press.

Baker, D., Kjellström, C. R., \& Pastides, H. (Eds.). (1999). Environmental Epidemiology: A Textbook on Study Methods and Public Health Applications. World Health Organization, Geneva (WHO/SDE/OEH/99.7).

Benson, J., \& Clark, F. (1983). A guide for instrument development and validation. American Journal of Occupational Therapy, 36, 789-800. http://dx.doi.org/10.5014/ajot.36.12.789

Bluedorn, A. C. (1982). A unified model of turnover from organizations. Human Relations, 35, 135-153. http://dx.doi.org/10.1177/001872678203500204 
Burgess, H. J., Sharkey, K. M., \& Eastman, C. I. (2002). Bright light, dark and melatonin can promote circadian adaptation in night shift workers. Medical Reviews, 6(5), 407-420.

Chruden, H. J., \& Sherman, A. W. (1972). Personal management. South-Western, Philippine.

Colquitt, J. A., Conlon, D. E., Wesson, M. J., Porter, C. O. L. H., \& Ng, K. Y. (2001). Justice at the millennium: A meta-analytic review of 25 years of organizational justice research. Journal of Applied Psychology, 86, 425-445. http://dx.doi.org/10.1037/0021-9010.86.3.425

Costa, G. (1996). The impact of shift and night work on health. Applied Ergonomics, 27(1), 9-16. http://dx.doi.org/10.1016/0003-6870(95)00047-X

Cotton, J. L., \& Tuttle, J. M. (1986). Employee turnover: A meta-analysis and review with implications for research. Academy of Management Review, 11, 55-70.

Creswell, J. W. (1998). Qualitative inquiry and research design: Choosing among five traditions. Thousand Oaks, CA: Sage Publications.

Creswell, J. W. (2008). Educational research: Planning, conducting, and evaluating quantitative and qualitative research (3rd ed.). Upper Saddle River, NJ: Pearson Prentice Hall.

Custer, R. L., Scarcella, J. A., \& Stewart, B. R. (1999). The modified Delphi technique: A rotational modification. Journal of Vocational and Technical Education, 15(2), 1-10

Dalkey, N. C., \& Helmer, O. (1963). An experimental application of the Delphi method to the use of experts. Management Science, 9(3), 458-467. http://dx.doi.org/10.1287/mnsc.9.3.458

Davidison, M. (2006). Hotel industry losing millions in staff turnover. Retrieved May 29, 2012, from http://www.careerone.com.au/jobs/job-search/job-arketinsider/hotel-industry-losing-millions-in-staff-turnov er-report

Decker, F., Gruhn, P., Martin, L., Dollard, K., Tucker, A., \& Bizette, L. (2003). Results of the 2002 AHCA Survey of Nursing Staff Vacancy and Turnover in Nursing Homes. Retrieved March 20, 2012, from http://www.ahca.org/research/rpt_vts2002_final.pdf

Dewe, P. J. (1989). Examining the nature of work stress: Individual evaluations of stressful experiences and coping. Journal of Human relations, 42(11), 993-1013. http://dx.doi.org/10.1177/001872678904201103

Einarsen, S., Hoel, H., Zapf, D., \& Cooper, C. L. (2011). The Concept of Bullying and Harassment at Work: The European Tradition. In S. Einarsen, H. Hoel, D. Zapf, \& C. L. Cooper (Eds.), Bullying and Harassment in the Workplace (pp. 3-39). Developments in Theory, Research, and Practice. CRC Press, Taylor \& Frances Group, Boca Raton, London, New York.

Eisenberger, R., Armeli, S., Rexwinkel, B., Lynch, P. D., \& Rhoades, L. (2001). Reciprocation of perceived organizational support. Journal of Applied Psychology, 86(1), 42-51. http://dx.doi.org/10.1037/ 0021-9010.86.1.42

Eisenberger, R., Fasolo, P., \& Davis-LaMastro, V. (1990). Perceived organizational support and employee diligence, commitment, and innovation. Journal of Applied Psychology, 75(1), 51-59. http://dx.doi.org/10.1037/0021-9010.75.1.51

Eisenhardt, K. M. (1989). Building theories from case study research. Academy of Management Review, 14(4), $532-550$.

Ferreira. (2007). In S. O. Michael (Ed.), Using Motivational Strategy as Panacea for Employee Retention and Turnover in Selected Public and Private Sector Organizations in the Eastern Cape Province of South Africa. Master of Commerce Thesis, University of Fort Hare.

Fields, J. (2005). New Drive to Cut Staff Turnover in Tourism. Retrieved May, 2012, from http://findarticles.com/p/mi_qn4156/is_20051211/ai_n15917264

French, J. R. P., \& Caplan, R. D. (1973). In A. J. Marrow (Ed.), Organizational Stress and Individual Strain, in the Failure of Success (pp. 30-66). New York: John Wiley.

Gall, J. P., \& Gall, M. D. (1998). Instructor's Manual (4th ed.). New York: Longman.

Gwavuya, F. (2011). Leadership Influences on Turnover Intentions of Academic Staff in Institutions in Zimbabwe. Academic Leadership Journal, 9(1), 1-15.

Hackman, J. R., \& Oldham, G. R. (1975). The Development of the Job Diagnostic Survey. Journal of Applied 
Psychology, 60, 159-170. http://dx.doi.org/10.1037/h0076546

Hair, J. F., Black, W. C., Babin, B. J., \& Anderson, R. E. (2010). Multivariate Data Analysis (7th ed.).

Halsey, A. H., Heath, A., \& Ridge, J. (1980). Origins and Destinations. Oxford University Press, Oxford.

Hatton, C., Emerson, E., Rivers, M., Mason, H., Swarbrik, R., Mason, L., ..., Albroz, A. (2001). Factors associated with intended turnover and job search behaviour in services for people with intellectual disability. Journal of Intellectual Disability Research, 45(3), 258-270. http://dx.doi.org/10.1046/j.1365-2788. 2001.00321.x

Homans, G. C. (1961). Social behavior: Its elementary forms. New York, NY: Harcourt, Brace \& World.

International Labour Organization. (2007). Report III (Part 1 B), General Survey concerning the Forced Labour Convention, 1930 (No.29), and the Abolition of Forced Labour Convention, 1957 (No. 105). International Labour Conference. 96th Session, Geneva.

Israel, B. A., Schurman, S. J., \& House, J. S. (1989). Action research on occupational stress: Involving workers as researchers. International Journal of Health Services, 19, 135-155. http://dx.doi.org/10.2190/ L2JF-U13W-FT0X-DFXM

Ivancevich, J. M., \& Matteson, M. T. (1980). Stress and Work: A Managerial Perspective. Scottforesman \& Co., Glen view Illinois.

Ivankova, N. V., Creswell, J. W., \& Stick, S. (2006, February). Using mixed methods sequential explanatory design: From theory to practice. Field Methods, 18(1), 3-20. http://dx.doi.org/10.1177/1525822X05282260

Jeffress, C. N. (2000, October 27). BEACON Biodynamics and Ergonomics Symposium. University of Connecticut, Farmington, Conn.

Kalliath, T. J., \& Beck, A. (2001). Is the path to burnout and turnover paved by a lack of supervisory support: A structural equations test. New Zealand Journal of Psychology, 30, 72-78.

Karasek, R. A., Gardell, B., \& Lindell, J. (1987). Work and non-work correlates of illness and behaviour in male and female Swedish white collar workers. Journal of Occupational Behaviour, 8, 187-207. http://dx.doi.org/10.1002/job.4030080302

Kramer, M. W., Callister, R. R., \& Turban, D. B. (1995). Information-receiving and information-giving during job transitions. Western Journal of Communication, (59), 151-170. http://dx.doi.org/ $10.1080 / 10570319509374513$

Lang, P. J. (1984). Cognition in emotion: Concept and action. In C. E. Izard, J. Kagan, \& R. B. Zajonc (Eds.), Emotions, Cognition, and Behavior. Cambridge University Press, New York.

Larson, S., \& Lakin, K. (1999). Longitudinal Study of Recruitment and Retention in Small Community Homes Supporting Persons with Developmental Disabilities. Mental Retardation, 37(4), 267-280. http://dx.doi.org/10.1352/0047-6765(1999)037<0267:LSORAR>2.0.CO;2

Leventhal, G. S. (1980). What should be done with equity theory? New approaches to the study of fairness in social relationships. In K. Gergen, M. Greenbers, \& R. Willis (Eds.), Social Exchange: Advances in Theory and Research (pp. 27-55). New York: Plenum. http://dx.doi.org/10.1007/978-1-4613-3087-5_2

Levinson, H. (1965). Reciprocation: The relationship between man and organization. Administrative Science Quarterly, 9, 370-390. http://dx.doi.org/10.2307/2391032

Lind, E. A., \& Tyler, T. R. (1988). The social psychology of procedural justice. New York, NY: Plenum. http://dx.doi.org/10.1007/978-1-4899-2115-4

Louis, M. R. (1980). Surprise and sense making: What newcomers experience in entering unfamiliar organizational settings. Administrative Science Quarterly, 25, 226-248. http://dx.doi.org/10.2307/2392453

Ludwig, B. (1997). Predicting the future: Have you considered using the Delphi methodology? Journal of Extension, 35(5), 1-4. Retrieved November 6, 2005, from http://www.joe.org/joe/1997october/tt2.html

Lundberg, U. (2000). Workplace stress. Encyclopaedia of stress, 3, 684-691.

Maanen, V. J., \& Schein, E. H. (1979). Toward of Theory of Organizational Socialization. Research in Organizational Behavior, 1, 209-264.

Malhotra, N. K. (2010). Marketing Research: An Applied Orientation. New Jersey: Pearson Education.

Manzini, H., \& Gwandure, C. (2011). The Provision of Employee Assistance Programmes in South Africa 
Football Clubs. University of the Witwatersrand, Johannesburg. South Africa.

Masahudu, G. O. (2008). Why it is Difficult to Retain Employees? Why Retain Employee? Retrieved February 14, 2010, from http://knol.google.com/k/osman-masahudu-gunu/why-it-is-difficult-to-retainemployees/ 1 kietb77pgwru/2

Miller, D. (2000). Qualitative Research Course Packet. University of Nebraska-Lincoln.

Miller, V. D., \& Jablin, F. M. (1991). Information seeking during organizational entry: Influences, tactics, and a model of the process. Academy of Management Review, 16(1), 92-120.

NIOSH. (2003). Citation in: Human factors and ergonomics. Retrieved April 22, 2012, from http://en.wikipedia.org/wiki/Human_factors_and_ergonomics

Nunnally, J. C. (1978). Psychometric theory (2nd ed.). New York: McGraw-Hill.

Occupational Ergonomics Program. (2013). Fitting the Task to The worker: Environmental Health and Safety Office. University of Minesota, Duluth.

Opatha, H. H. N. D. P. (2003). Towards Effective Worker Grievance Handling Some Reflections. Management Matters, 1(3).

Orpen, C. (1979). The Effects of Job Enrichment on Employee Satisfaction, Motivation, Involvement, and Performance. Journal of Human Relations, 32, 189-217. http://dx.doi.org/10.1177/001872677903200301

OSHA. (2013). Workplace Ergonomics: NIOSH Provides Steps to Minimize Musculoskeletal Disorders. In C. N. Jeffress (Ed.), BEACON Biodynamics and Ergonomics Symposium. University of Connecticut, Farmington, Conn. 3. Palo Alto, CA: Consulting Psychologist Press.

Pallant, J. (2001). The SPSS survival manual: A step-by-step guide to data analysis using SPSS for Windows (Version 10). St Leonards, NSW: Allen \& Unwin, Palo Alto, CA: Consulting Psychologist Press.

Peter, J. P. (1979). Reliability: A Review of Psychometric Basics and Recent Marketing Practices. Journal of Marketing Research, 26, 6-17. http://dx.doi.org/10.2307/3150868

Peters, L., Bhagat, R., \& O'Connor, E. J. (1981). An examination of the independent and joint contribution of organizational commitment and job satisfaction on employee intention to quit. Group Organizational Studies, 6, 73-82. http://dx.doi.org/10.1177/105960118100600108

Pfeiffer, J. (1968.). New look at education: Systems analysis in our schools and, colleges. New York: The Odyssey Press.

Polit, F., \& Hungler, B. P. (1993). Essentials of nursing research: Appraisal and utilization (3rd ed.). Pennsylvania: JB Lippincott. Prentice Hall, Upper Saddle River, New Jersey.

Priti, S. (2009). Employee Welfare. Retrieved July 1, 2012, from http://www.citehr.com/176307-employeewelfare.html \#ixzz1zTZ8HheC

Quinn, R. P., Seashore, S., \& Mangione, I. (1971). Survey of Working Conditions. Washington, DC: US Government Printing Office.

Rhoades, L., Eisenberger, R., \& Armeli, S. (2001). Affective commitment of the organization: The contribution to perceived organizational support. Journal of Applied Psychology, 86(5), 825-836. http://dx.doi.org/10.1037/0021-9010.86.5.825

Royalty, \& Beeson, A. (1996). The Effects of Job Turnover on the Training of Men and Women. Industrial and Labour Relations Review, 49(3), 506-521. http://dx.doi.org/10.2307/2524200

Saifuddin, Hongkrailert, N., \& Sermsri, S. (2008). Job Satisfaction among nurses in Aceh Timer district Nanggroe Aceh Darussalam province Indonesia. Health and Development Journal, 6(1), 155.

Saks, A. M. (1996). The relationship between the amount of helpfulness of entry training and work outcomes. Human Relations, 49, 429-451. http://dx.doi.org/10.1177/001872679604900402

Saunders, M., Lewis, P., \& Thornhill, A. (2009). Research Methods for Business Students (5th ed.). New Jersey: Prentice Hall.

Schuler, R. S., \& Jackson, S. E. (1996). Human Resource Management. West Publishing Company. New York.

Shaw, J. D., Delery, J. E., Jenkins, G. D., \& Gupta, N. (1998). An organization-level analysis of voluntary and involuntary turnover. Academy of Management Review, 41(5), 511-525. http://dx.doi.org/10.2307/256939 
Trevor, C. O., Gerhart, B., \& Boudreau, J. W. (1997). Voluntary turnover and job performance Curvilinearity and the moderating influences of salary growth and promotions. Journal of Applied Psychology, 82, 44-61. http://dx.doi.org/10.1037/0021-9010.82.1.44

Turoff, M., \& Hiltz, S. R. (1996). Computer based Delphi process. In M. Adler, \& E. Ziglio (Eds.), Gazing into the oracle: The Delphi method and its application to social policy and public health (pp. 56-88). London, UK: Jessica Kingsley Publishers.

Ulschak, F. L. (1983). Human resource development: The theory and practice of need assessment. Reston, VA: Reston Publishing Company, Inc.

Watkins. (1953). The Personal Turnover Concept: A Reappraisal. Public Administration Review, 17(4), 247-256.

Wayne, S. J., Shore, L. M., \& Liden, R. C. (1997). Perceived organizational support and leader-member exchange: A social exchange perspective. Academy of Management Journal, 40, 82-111. http://dx.doi.org/ $10.2307 / 257021$

Yin, R. K. (2003). Case Study Research: Design and Methods. Thousand Oakds: Sage Publications.

Zaleznik, A., \& Kets de Vries, M. F. R. (1977). Stress Reactions in Organizations: Syndromes, Causes and Consequences. Behavioral Science, 22, 151-162. http://dx.doi.org/10.1002/bs.3830220302

\section{Appendix A}

\section{Intention to Stay Instrument (ISI)}

In the following pages, there are number of questions that may reflect your thoughts in association with your intention to stay in an organization. By using a scale ranging from strongly disagree to strongly agree, please choose the degree of agreement with your current circumstances by ticking $(\sqrt{ })$ on the square provided in every question that most accurately reflects your perceptions. If you have trouble in understanding a question, answer to the best of your ability. You are required to answer these questions, which truly describe yourself. Your answers are very important to the accuracy of this study. (Please return the completed questionnaire in the enclosed self-addressed envelope at your earliest convenience).

Appendix A1.

\begin{tabular}{|c|c|c|c|c|c|c|c|c|c|c|c|}
\hline \multicolumn{12}{|l|}{ Questions } \\
\hline & \multicolumn{11}{|c|}{ I feel that this organization is making provision of better career path. } \\
\hline & 1 & 2 & 3 & 4 & 5 & 6 & 7 & 8 & 9 & 10 & \\
\hline & \multicolumn{11}{|c|}{ I feel that the career promotion is based on merit and performance. } \\
\hline & 1 & 2 & 3 & 4 & 5 & 6 & 7 & 8 & 9 & 10 & \\
\hline & \multicolumn{11}{|c|}{ I feel that this organization is making provision of better career oriented positions. } \\
\hline & 1 & 2 & 3 & 4 & 5 & 6 & 7 & 8 & 9 & 10 & \\
\hline & \multicolumn{11}{|c|}{ I feel that my career options are well taken care by the organization. } \\
\hline & 1 & 2 & 3 & 4 & 5 & 6 & 7 & 8 & 9 & 10 & \\
\hline & \multicolumn{11}{|c|}{ I feel that the organization provides better pay in correlation with the effort I put. } \\
\hline & 1 & 2 & 3 & 4 & 5 & 6 & 7 & 8 & 9 & 10 & \\
\hline & \multicolumn{10}{|c|}{ I feel I am getting better pay in comparison with other organizations. } & Strongly \\
\hline \multirow{11}{*}{ Disagree } & 1 & 2 & 3 & 4 & 5 & 6 & 7 & 8 & 9 & 10 & Agree \\
\hline & \multicolumn{11}{|c|}{ I feel that the perks, allowances and other fringe benefits are up to our expectations } \\
\hline & 1 & 2 & 3 & 4 & 5 & 6 & 7 & 8 & 9 & 10 & \\
\hline & \multicolumn{11}{|c|}{ I feel that there is no discrimination on bonus or other fringe benefits distribution in this organization } \\
\hline & 1 & 2 & 3 & 4 & 5 & 6 & 7 & 8 & 9 & 10 & \\
\hline & \multicolumn{11}{|c|}{ I feel that the induction programs are sufficient enough for better employee orientation } \\
\hline & 1 & 2 & 3 & 4 & 5 & 6 & 7 & 8 & 9 & 10 & \\
\hline & \multicolumn{11}{|c|}{ I feel that the induction training programs are adequate to start working from day one } \\
\hline & 1 & 2 & 3 & 4 & 5 & 6 & 7 & 8 & 9 & 10 & \\
\hline & \multicolumn{11}{|c|}{ I feel that the organization is making provision of better personal development programs } \\
\hline & 1 & 2 & 3 & 4 & 5 & 6 & 7 & 8 & 9 & 10 & \\
\hline
\end{tabular}


I am confident about my professional and personal development by working in this organization

$\begin{array}{llllllllll}1 & 2 & 3 & 4 & 5 & 6 & 7 & 8 & 9 & 10\end{array}$

I feel the top management always listen the concerns of employees

$\begin{array}{llllllllll}1 & 2 & 3 & 4 & 5 & 6 & 7 & 8 & 9 & 10\end{array}$

I am seldom worried about management punitive actions against members

$\begin{array}{llllllllll}1 & 2 & 3 & 4 & 5 & 6 & 7 & 8 & 9 & 10\end{array}$

I feel that I am enjoying my organizational and work freedom very much in this organization

$\begin{array}{llllllllll}1 & 2 & 3 & 4 & 5 & 6 & 7 & 8 & 9 & 10\end{array}$

I feel that the job I perform is highly specialized and non-substitutable with common skills

$\begin{array}{llllllllll}1 & 2 & 3 & 4 & 5 & 6 & 7 & 8 & 9 & 10\end{array}$

I feel that the job I perform is challenging

$\begin{array}{llllllllll}1 & 2 & 3 & 4 & 5 & 6 & 7 & 8 & 9 & 10\end{array}$

I feel that the job I perform is seldom monotonous

$\begin{array}{llllllllll}1 & 2 & 3 & 4 & 5 & 6 & 7 & 8 & 9 & 10\end{array}$

I feel that the job I perform is interesting due to its diversity

$\begin{array}{llllllllll}1 & 2 & 3 & 4 & 5 & 6 & 7 & 8 & 9 & 10\end{array}$

I am well satisfied with the terms and conditions of the organization

$\begin{array}{llllllllll}1 & 2 & 3 & 4 & 5 & 6 & 7 & 8 & 9 & 10\end{array}$

I feel that the terms and conditions of my job is very much clear and employee friendly

Strongly

$\begin{array}{llllllllllll}1 & 2 & 3 & 4 & 5 & 6 & 7 & 8 & 9 & 10 & \text { Agree }\end{array}$

I feel that the terms and conditions of my job bring on better safety and security

$\begin{array}{llllllllll}1 & 2 & 3 & 4 & 5 & 6 & 7 & 8 & 9 & 10\end{array}$

I feel that the terms and conditions of the organizations are more tolerable compared to other organizations

$\begin{array}{llllllllll}1 & 2 & 3 & 4 & 5 & 6 & 7 & 8 & 9 & 10\end{array}$

I feel that the working hours are more flexible in this organization

$\begin{array}{llllllllll}1 & 2 & 3 & 4 & 5 & 6 & 7 & 8 & 9 & 10\end{array}$

I feel that the employees are expected to work only in the regular working hours

$\begin{array}{llllllllll}1 & 2 & 3 & 4 & 5 & 6 & 7 & 8 & 9 & 10\end{array}$

I feel that the employees are getting flexible shift work

$\begin{array}{llllllllll}1 & 2 & 3 & 4 & 5 & 6 & 7 & 8 & 9 & 10\end{array}$

I am satisfied with the working hours and schedule

$\begin{array}{llllllllll}1 & 2 & 3 & 4 & 5 & 6 & 7 & 8 & 9 & 10\end{array}$

I feel that the working condition is not at all taxing the employee health

$\begin{array}{llllllllll}1 & 2 & 3 & 4 & 5 & 6 & 7 & 8 & 9 & 10\end{array}$

I feel that the organizational physical layout is well taken care employee health

$\begin{array}{llllllllll}1 & 2 & 3 & 4 & 5 & 6 & 7 & 8 & 9 & 10\end{array}$

I usually get adequate rest during my work hours

$\begin{array}{llllllllll}1 & 2 & 3 & 4 & 5 & 6 & 7 & 8 & 9 & 10\end{array}$

I feel that the organization is making the provision of better health care facilities within the organizational premises

$\begin{array}{llllllllll}1 & 2 & 3 & 4 & 5 & 6 & 7 & 8 & 9 & 10\end{array}$

I feel that the organization is well taken care of employee fitness at work

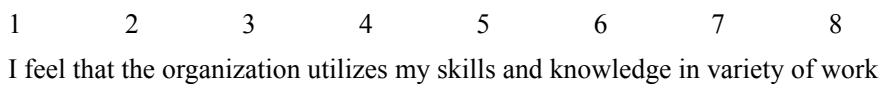

$\begin{array}{llllllllll}1 & 2 & 3 & 4 & 5 & 6 & 7 & 8 & 9 & 10\end{array}$

The job makes use of multi-skills

$\begin{array}{llllllllll}1 & 2 & 3 & 4 & 5 & 6 & 7 & 8 & 9 & 10\end{array}$

I have high enthusiasm to stay back at work and organization

$\begin{array}{llllllllll}1 & 2 & 3 & 4 & 5 & 6 & 7 & 8 & 9 & 10\end{array}$

I am well satisfied with the work I am engaged into

$\begin{array}{llllllllll}1 & 2 & 3 & 4 & 5 & 6 & 7 & 8 & 9 & 10\end{array}$ 
I feel that there is no overloaded at work

$\begin{array}{llllllllll}1 & 2 & 3 & 4 & 5 & 6 & 7 & 8 & 9 & 10\end{array}$

I feel that the work is not tiring to my abilities and skills

$\begin{array}{llllllllll}1 & 2 & 3 & 4 & 5 & 6 & 7 & 8 & 9 & 10\end{array}$

I feel that there is no difficulty in performing the job

$\begin{array}{llllllllll}1 & 2 & 3 & 4 & 5 & 6 & 7 & 8 & 9 & 10\end{array}$

I feel that the in time guidance and training decreases the workload

$\begin{array}{llllllllll}1 & 2 & 3 & 4 & 5 & 6 & 7 & 8 & 9 & 10\end{array}$

I have a good relationship with my co-workers.

$\begin{array}{llllllllll}1 & 2 & 3 & 4 & 5 & 6 & 7 & 8 & 9 & 10\end{array}$

I feel that my co-workers better cooperate with each other

$\begin{array}{llllllllll}1 & 2 & 3 & 4 & 5 & 6 & 7 & 8 & 9 & 10\end{array}$

My co-workers usually supports me during job difficulties

$\begin{array}{llllllllll}1 & 2 & 3 & 4 & 5 & 6 & 7 & 8 & 9 & 10\end{array}$

I usually better connect with my co-workers

$\begin{array}{llllllllll}1 & 2 & 3 & 4 & 5 & 6 & 7 & 8 & 9 & 10\end{array}$

I usually get better support from my supervisors

$\begin{array}{llllllllll}1 & 2 & 3 & 4 & 5 & 6 & 7 & 8 & 9 & 10\end{array}$

I feel that our supervisors provide the proper guidance at work

$\begin{array}{llllllllll}1 & 2 & 3 & 4 & 5 & 6 & 7 & 8 & 9 & 10\end{array}$

My supervisors usually encourage experimentation at work

$\begin{array}{llllllllll}1 & 2 & 3 & 4 & 5 & 6 & 7 & 8 & 9 & 10\end{array}$

I feel that the mistakes happen during work are well guided by the supervisors

$\begin{array}{llllllllll}1 & 2 & 3 & 4 & 5 & 6 & 7 & 8 & 9 & 10\end{array}$

I feel that the mistakes suggestions and innovations are highly welcomed at work

$\begin{array}{llllllllll}1 & 2 & 3 & 4 & 5 & 6 & 7 & 8 & 9 & 10\end{array}$

I feel that the achievements at work are well recognized

I feel that the organization encourages continuous feedback and appreciates good work
1
2
3
4
$\begin{array}{lll}5 & 6 & 7\end{array}$
89
10

Strongly

Continuous engagement at work due to motivation

$\begin{array}{llllllllll}1 & 2 & 3 & 4 & 5 & 6 & 7 & 8 & 9 & 10\end{array}$

I feel that the leaders in this organization is very much supportive

$\begin{array}{llllllllll}1 & 2 & 3 & 4 & 5 & 6 & 7 & 8 & 9 & 10\end{array}$

I feel that the management leadership is motivating

$\begin{array}{llllllllll}1 & 2 & 3 & 4 & 5 & 6 & 7 & 8 & 9 & 10\end{array}$

I feel that the management leadership value oriented

$\begin{array}{llllllllll}1 & 2 & 3 & 4 & 5 & 6 & 7 & 8 & 9 & 10\end{array}$

I feel that there is better work orientation to members

$\begin{array}{llllllllll}1 & 2 & 3 & 4 & 5 & 6 & 7 & 8 & 9 & 10\end{array}$

I feel that there is well-designed job description

$\begin{array}{lllllllllll}1 & 2 & 3 & 4 & 5 & 6 & 7 & 8 & 9 & 10\end{array}$

I feel that there is better job exposure to newcomers.
1 2
$\begin{array}{llll}3 & 4 & 5 & 6\end{array}$
$\begin{array}{lll}8 & 9 & 10\end{array}$

$6 \quad 7$

I feel that there is maximum utilization of skills and less wastage
12
34
$5 \quad 6 \quad 7$
10

$8 \quad 9$

I feel that the probation period is satisfactory to the employees 
Questions

$\begin{array}{llllllll}1 & 2 & 3 & 4 & 5 & 6 & 7 & 8\end{array}$

I feel that the location of the organization facilitates better entertainment and leisure

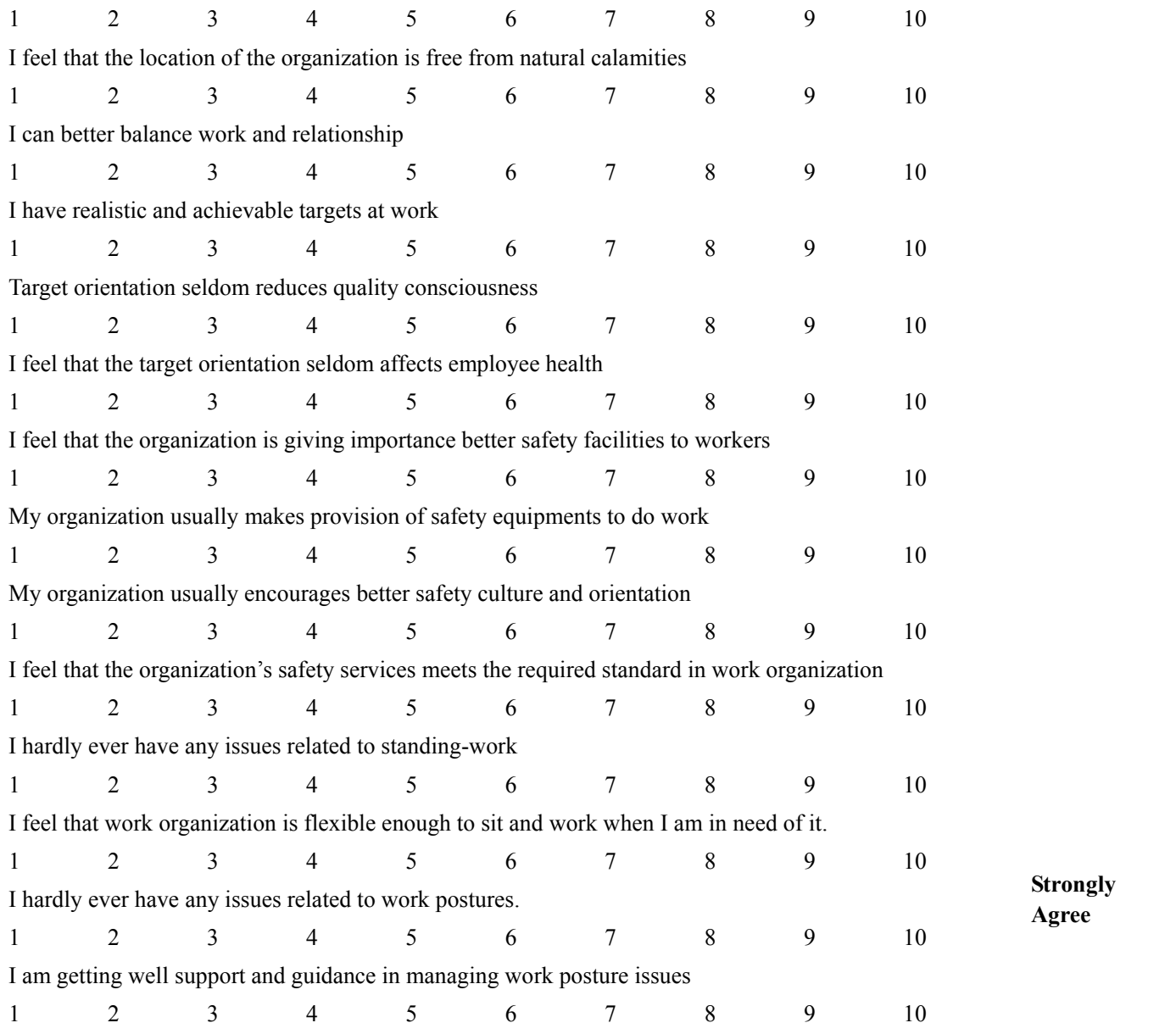

\section{Copyrights}

Copyright for this article is retained by the author(s), with first publication rights granted to the journal.

This is an open-access article distributed under the terms and conditions of the Creative Commons Attribution license (http://creativecommons.org/licenses/by/3.0/). 